\title{
A DECENTRALIZÁLT TERÜLETFEJLESZTÉSI TÁMOGATÁSOK FELHASZNÁLÁSÁNAK TAPASZTALATAI A NYUGAT-DUNÁNTÚLI RÉGIÓBAN
}

\author{
(Experiences of the Expenditures of the Decentralised Regional \\ Development Supports in West Transdanubia)
}

\section{GROSZ ANDRÁS}

Kulcsszavak:

területfejlesztés finanszirozás Nyugat-Dunántúl

A területfejlesztési és területrendezési törvény elfogadásával 1996-ban megkezdödött a területfejles:tési támogatások megyei szintre történō decentralizációja. A megyék társadalmigazdasági fejlettségi szintjében megmutatkozó különbségek viszonylag jól visszatükrözôdnek a támogatások megyék kỏzötti elosztásában, azonban rendkivül alacsony összegüknél fogva alkalmatlanok hosszú távú stratégiai célok megvalósitására. Mindazonáltal a támogatások elösegitették a megyék dinamikus fejlödéséhez szukséges feltételek megteremtését, és jelentōs mértékben hozzajárultak a magyar területfejlesztés EU kompatibilis intézmény-és eszközrendszerének kialakitásáho=.

Immár öt esztendő telt el a hazai területfejlesztés eszköz- és intézményrendszerét részletesen szabályozó 1996. évi XXI. a területfejlesztésröl és területrendezésröl szóló törvény (továbbiakban Tf. tv.) elfogadása óta. A terủletfejlesztés eszközrendszerének szabályozását illetően a Tf. tv. egyik legjelentősebb elörelépése egyértelmúen - a decentralizációval, az EU regionális politikájának elvével őszhangban - az az elóírás, hogy a közvetlen terủletfejlesztési célokat szolgáló források legalább 50\%-át decentralizálni kell. E decentralizált pénzeszkőzök kedvezményezettjei kezdetben az ugyancsak a törvény által újonnan létrehozott megyei területfejlesztési tanácsok voltak, melyek feladata, hogy a megyék hosszú távú stratégiai céljaival, és az azok elérése érdekében megfogalmazott fejlesztési prioritásokkal összhangban használják fel a rendelkezésre álló forrásokat. Természetesen a megye fejlesztési elképzeléseinek érvényesítése mellett igazodni kell a források felhasználására vonatkozó központi szabályozáshoz is. 2001-tỏl kezdődóen a decentralizált terủletfejlesztési források egy részének a regionális fejlesztési tanácsokhoz való csoportosításával felhasználásában szerepet kapott a központi kormányzat alatti első közvetlen szubszidiárus szint is, a régió.

Jelen tanulmány célja, hogy bemutassa a megyei decentralizált területfejlesztési források - a terủletfejlesztési célelöirányzat (TFC), a területi kiegyenlítést szolgáló fejlesztési célú támogatás (TERKI) és a céljellegü decentralizált alap (CÉDE) felhasználásának legfontosabb tapasztalatait. A vizsgálat célja feltárni a leggyakoribb felhasználási célokat, a támogatásban részesulló pályázók ossszetételét, 
a támogatások által generált fejlesztések volumenét. Ugyancsak célja a tanulmánynak, hogy megvizsgálja a törvény megszületését követően megélénkült területi tervezési folyamat során elkészült dokumentumokban (megyei területfejlesztési koncepciók, stratégiák) megfogalmazott célkitüzések és fejlesztési prioritások megvalósítása, valamint a decentralizált pénzeszközök felhasználása közötti összhangot, kapcsolatot. Ezzel hozzájárulhat annak megismeréséhez, hogy a decentralizált fejlesztési pénzeszközök milyen mértékben képesek hozzájárulni a fejlesztési dokumentumokban meghatározásra került elképzelések megvalósításához.

A tanulmány elsỏ részében mindenekelött szeretnénk bemutatni a megyei decentralizált pénzeszközök, illetve felhasználásuk jogszabályi hátterét, a decentralizációt meghatározó elveket és az azok felhasználására vonatkozó központi szabályozást, valamint a megyei szinten rendelkezésre álló forrásokat. Ezt követöen egy mintatérséget kiválasztva szeretnénk a területfejlesztési források felhasználásának vizsgálatát elvégezni. A vizsgálat célterületét a Nyugat-dunántúli régió három megyéje (Györ-Moson-Sopron, Vas és Zala) adja. A megyei szint adott, hiszen e források felhasználása a megyei területfejlesztési tanácsok döntési jogköréhez tartozik, míg a Nyugat-dunántúli régió kiválasztását az intézetben ${ }^{1}$ az elmúlt években folytatott, a területi tervezés szabályozásához, valamint a területfejlesztés finanszírozási rendszeréhez kapcsolódó különböző kutatások indokolják.

A vizsgálat alapját az egyes megyékben a megyei területfejlesztési tanácsok által pályázati úton megítélt területfejlesztési támogatások alkotják (1996-1999 között), az adatokat a tanácsok munkaszervezetei bocsátották rendelkezésünkre. Az adatok elemzéséhez ugyanakkor jelentős mértékben hozzájárultak a megyei területfejlesztési tanácsok munkaszervezeteinek vezetőivel készitett személyes interjúk is. Végül szeretnénk megjegyezni, hogy jelen tanulmány kizárólag a decentralizált megyei pénzeszközökre koncentrál, és nem kíván foglalkozni a régió számára rendelkezésre álló PHARE CBC források felhasználásával.

\section{A területfejlesztés megyei eszközei}

A területfejlesztés eszköz- és intézményrendszerében 1996 óta fontos szerepet tölt be az újonnan felállitott megyei területfejlesztési tanács, illetve a tanács hatáskörébe utalt, ún. területfejlesztést szolgáló decentralizált pénzeszközök. A megyei területfejlesztési tanácsok 1996-tól két decentralizált eszköz felett rendelkeznek, amelyek 1998-ban egy további forrás elosztásával egészültek ki.

A területfejlesztési célelőirányzat (továbbiakban TFC) ${ }^{3}$ felhasználását szabályozó rendelet értelmében elsödlegesen - a társadalmi és gazdasági fejlettségben megmutatkozó különbségek csökkentése, az átfogó szerkezetátalakítás és térségi együttmüködés elösegítése, valamint a nemzetközi, vállalkozói és befektetői tőke területfejlesztési programokba való integrálása érdekében - gazdaságfejlesztési, 
termelöinfrastruktúra-fejlesztési, munkahely-teremtési és humánerőforrásfejlesztési célokat szolgál ${ }^{4}$. A TFC-bỏl támogatásban részesíthetök az önkormányzatok, illetve a vállalkozói szféra által megvalósított - a központi szabályozás céljaival összhangban lévő - fejlesztések és beruházások. Támogatásra csak a kedvezményezett térségekben vagy településeken ${ }^{5}$ megvalósuló projekt jogosult, kivéve, ha az valamely regionális, térségi, megyei vagy kistérségi fejlesztési program keretében, illetve vállalkozási övezetben vagy ipari parkban valósul meg. A területi kiegyenlítést szolgáló elöirányzat (TERKI) a termelő infrastrukturális feltételekben meglévő különbségek mérséklésére az önkormányzatok kommunális jellegü infrastrukturális fejlesztéseinek finanszírozására irányul ${ }^{6}$. Támogatásából kizárólag a kedvezményezett térségek, illetve a kedvezményezett települések önkormányzatai részesedhetnek. Kivételt képeznek azok az önkormányzatok, amelyek kedvezményezettnek minösulő önkormányzattal együtt közös projekt megvalósításában vesznek részt, vagy ha a támogatandó projekt egyértelmüen pozitív hatással van a kedvezményezett térségekre is. 1998-tól kezdve a helyi önkormányzatok felhalmozási, valamint vis major kiadásainak támogatására létrehozták a céljellegü decentralizált elöirányzatot (CÉDE), amely az előbbi két decentralizált forrást egészíti $\mathbf{k i}^{7}$. A céljellegủ decentralizált előirányzatból, a területi kiegyenlítést szolgáló előirányzathoz hasonlóan szintén csak önkormányzatok részesülhetnek. Mivel célja nem kifejezetten területfejlesztési vagy felzárkóztatási, és felhasználása nem kapcsolódik a kedvezményezett térségek köréhez, ezért e forrásból a föváros is részesedhet.

1996 és 2001 között a TFC keretösszege folyóáron számolva meghaladta a 30 Mrd Ft-ot, míg a TERKI támogatásoké megközelítőleg 53,5 Mrd Ft volt. 1998-tól mintegy 23 Mrd Ft-ot tettek ki a CÉDE számára rendelkezésre álló pénzeszközök (1. táblázat). A kilencvenes évek végén mind a TFC, mind a TERKI összege évröl évre kis mértékủ emelkedést mutatott. Ez az emelkedés azonban nem volt képes lépést tartani az infláció mértékével, így reálértékét tekintve enyhe csökkenés tapasztalható, amit 1999-ig ellensúlyozni tudott a CÉDE támogatások 1998-as bevezetése és dinamikus emelkedése. 2001-ben azonban már nominálértékben is a decentralizált területfejlesztési források nagyságának csökkenése tapasztalható. A TFC támogatások összege 2001-ben reálértéken (1996-os árakon 2981 millió Ft) alig haladja meg az 1996-os érték 60\%-át (1. ábra). Ezt a csökkenést nem lehet csak azzal a változással magyarázni, hogy 2001-tól kezdve a területfejlesztési célelöirányzat 35\%-a a PHARE 2000 programból kimaradt régiókban megvalósuló hasonló programok finanszírozása céljából regionális szintre került átadásra, hiszen a megyei területfejlesztési tanácsok számára rendelkezésre álló TFC keret reálértéke 1996-tól folyamatosan csökken. A TERKI és a CÉDE viszonylag kiegyensúlyozottabbnak tekinthető, azonban az elmúlt évben már nominálértéken számolva is mérséklődött ezen elöirányzatok kerete. 


\section{TÁBLÁZAT}

A területfejlesztést szolgáló decentralizált pénzeszközök, 1996-2001

(folyóáron, millió Ft)

(Decentralised Sources of Regional Development, at Current Prices)

\begin{tabular}{lcrrrrrr}
\hline & 1996 & 1997 & 1998 & \multicolumn{1}{c}{1999} & \multicolumn{1}{c}{2000} & \multicolumn{1}{c}{2001} & $1996-2001$ \\
\hline TFC & 4700 & 5200 & 5500 & 5800 & 5516 & 5100 & 31816 \\
TERKI & 5000 & 8000 & 9000 & 10000 & 10900 & 10573 & 53473 \\
CEDE & - & - & 4000 & 6000 & 6540 & 6300 & 22840 \\
\hline Összesen & 9700 & 13200 & 18500 & 21800 & 22956 & 21973 & 108129 \\
\hline
\end{tabular}

Forrás: Complex CD-jogtár alapján saját számitás.

1. ÁBRA

A területfejlesztést szolgáló decentralizált pénzeszközök alakulảsa, 1996-2001

(1996-os árakon, millió Ft)

(Decentralised Sources of Regional Development, at 1996 Prices)

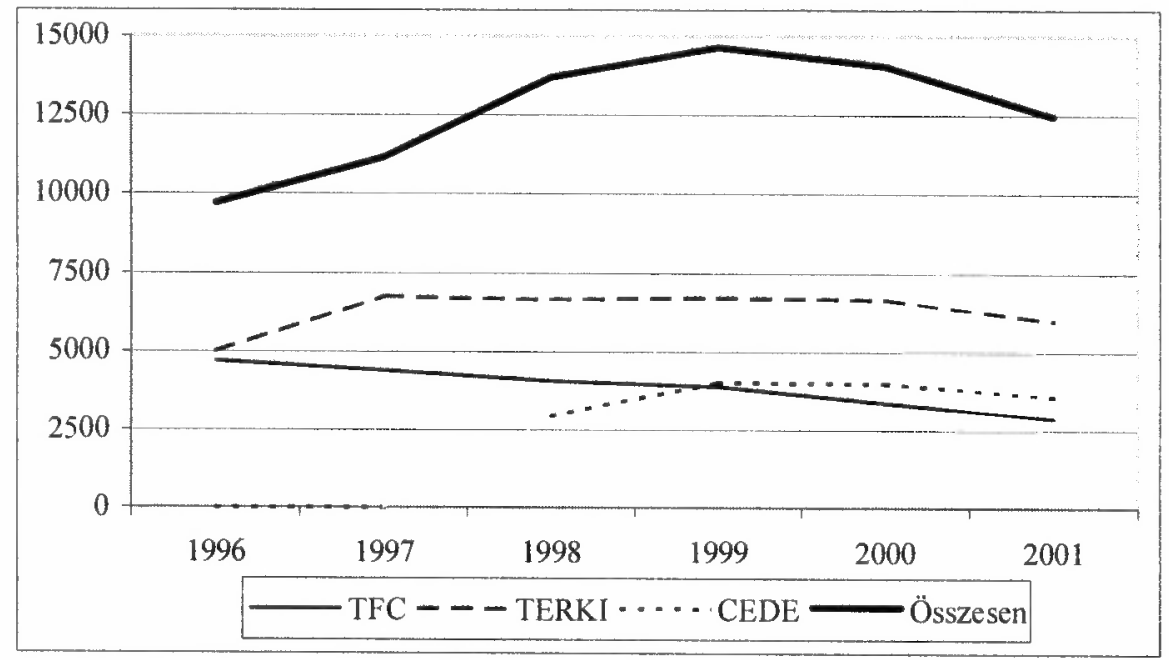

* A folyó áras számításhoz 2001. évre 8\%-os inflációt feltételeztünk.

Forrás: Complex CD jogtár alapján saját szerkesztés.

A decentralizált területfejlesztési támogatások megyék közötti elosztásának elveit országgyülési (OGY) határozat szabályozza ${ }^{8}$. A jogszabály alapján a területfejlesztési célelöirányzatok decentralizált kereteit a megyék lakónépessége, fejlettségi szintje (egy före jutó GDP) és a kedvezményezett térségek lakónépessége alapján kell meghatározni. Míg a TERKI teljes kerete felosztásra kerül a megyék között, addig a TFC-nek csak egy részét kell decentralizálni. 1996-tól 2000-ig ez a TFC 50\%-át jelentette (a fennmaradó 50\% a központi keretet adta), 2001-töl azonban a régiók helyzetbehozásával 30\%-ra csökkent a megyék részesedése a TFC-böl (a regionális fejlesztési tanácsok és a központi kormányzat egyaránt 35-35\%-kal rendelkeznek). 1996 és 2001 között egyértelmüen megfigyelhetö, hogy 
a támogatási keretösszegekből azok a megyék részesültek a legnagyobb támogatásban, amelyekben a legmagasabb volt a kedvezményezett térségekben élő lakosság száma, illetve aránya.

Ennek megfelelően az elmúlt hat évben az összes decentralizált pénzeszközböl a Közép-magyarországi, a Közép-dunántúli és a Nyugat-dunántúli régió megyéinek részesedése nem haladta meg a 9-9\%-ot, míg a Dunától keletre fekvő három régió megyéi egyuttesen a források $62 \%$-ával rendelkeztek. A legmagasabb az Északalföldi régió megyéinek a részesedése $24 \%-k a l$, de az Észak-magyarországiak is megközelítik a 20\%-ot. Különősen magas volt Borsod-Abaúj-Zemplén és SzabolcsSzatmár-Bereg megye részesedése, melyek külön-külön meghaladták a 10\%-ot. Ez közel ötszöröse a legkisebb támogatások felett diszponáló Vas megyei értéknek, de négyszeresen haladja meg a Györ-Moson-Sopron, a Komárom-Esztergom, vagy a Zala és Fejér megyei kereteket is. A TFC és a TERKI esetében az arányok még polarizáltabbak, hiszen ezek elosztása során figyelembe veszik a kedvezményezett térségben, településeken élők számát. Ezzel szemben a céljellegủ decentralizált támogatások - melyekból a kommunális fejlesztések mellett a humán infrastrukturális jellegű célokra, másrészt az elöre nem látható természeti vagy más károk által okozott vis maior többletkiadások fedezetére igyekeztek a teruletfejlesztési tanácsok támogatást biztosítani - összegének régiónkénti megoszlása valamivel kiegyenlitettebb képet mutat.

A decentralizált területfejlesztési támogatások nagysága eltörpül a nemzetgazdaság összes beruházása mellett, mindazonáltal pozitívnak mondható, hogy bár nagyon kis mértékben, de folyamatosan nő a beruházásokhoz viszonyított nagysága. 1996-ban a nemzetgazdaság által megvalósított 1338 Mrd Ft-os beruházásoknak mindössze 0,73\%-át adta, mely érték 1999-ben már megközelítette az $1 \%$-ot. Azonban, ha figyelembe vesszük a beruházások növekedését az elmúlt két évben és azt a tényt, hogy a támogatások összértéke 2001-ben közel azonos volt az 1999-es összeggel, akkor már ismét kedvezötlenebb a kép. Az országos szintü támogatásoknak a GDP-hez mért aránya is éppen, hogy csak eléri a $0,2 \%$-ot. Természetesen jelentős eltérések tapasztalhatók az egyes megyei értékek összehasonlításakor. 1999-ben, amikor a decentralizált területfejlesztési támogatások reálértéke a legmagasabb volt, a legfejlettebb Közép-magyarországi régióban - a beruházások budapesti koncentrációjának (részesedése a nemzetgazdaságból megközelítette a 46\%-ot), illetve az alacsony támogatásoknak köszönhetően - a támogatások aránya a beruházásokhoz viszonyítva mindössze $0,16 \%$ volt, de a Nyugat-dunántúli régióban sem érte el a 0,6\%-ot. Ezzel szemben $\mathrm{Az}$ Észak-alföldi régióban meghaladta a $3 \%$-ot, de a Dél-alföldi és az Északmagyarországi régióban is $2 \%$ feletti volt ez az érték. A legalacsonyabb és a legmagasabb érték között majdnem hússzoros a különbség, de ha a Középmagyarországi régiót speciális helyzete miatt nem is vesszük figyelembe, akkor is ötszörös. A támogatások GDP-hez mért aránya is tízszer annyi az Észak-alfơldi régióban, mint Közép-Magyarországon, de a Nyugat-dunántúli és a Középdunántúli értékeket is két és félszeresen meghaladja. 


\section{A Nyugat-dunántúli régióban rendelkezésre álló megyei decentralizált források}

A Nyugat-dunántúli régió - mint az ország egyik legdinamikusabban fejlődő térsége - az egy före jutó GDP-t tekintve a Közép-magyarországi régiót követően a második helyet foglalja el. Mindazonáltal a régió három megyéjét tekintve jelentős különbségek figyelhetök meg. Míg az egy före jutó GDP értéke a régióban, illetve Györ-Moson-Sopron és Vas megyében meghaladja, addig Zala megyében elmarad az országos átlagtól. Fejlettségének eredményeként a régió területén jóval kevesebb kedvezményezett térség és település található, mint az ország többi részén ${ }^{9}$. Ennek köszönhetỏen a kedvezményezett térségben, illetve településen élők számát tekintve a régió részesedése jóval alacsonyabb (4,9\%), mint a teljes lakónépesség esetében $(9,8 \%)$. Különösen igaz ez Vas megyére, ahol mindössze a népesség 12,8\%-a él kedvezményezett térségben vagy településen. A területfejlesztési támogatások megyék közötti allokációját befolyásoló mutatók értékeit a mintatérség három megyéjére a 2. táblázat foglalja össze.

\section{TÁBLÁZAT}

A területfejlesztési támogatảsok feltételrendszerének föbb mutatói a Nyugat-dunántüli régióban, 1997

(Main Indicators of the Conditions of Regional Development Supports in West Transdanubia)

\begin{tabular}{|c|c|c|c|c|c|c|c|c|}
\hline \multirow{4}{*}{ Megye, régió } & \multirow{2}{*}{\multicolumn{2}{|c|}{$\begin{array}{l}\text { Lakónépesség } \\
\text { 1997. jan. } 1 .\end{array}$}} & \multirow{2}{*}{\multicolumn{2}{|c|}{$\begin{array}{l}\text { Egy före jutó } \\
\text { GDP }\end{array}$}} & \multicolumn{4}{|c|}{ Kedvezményezett térség és telepulés } \\
\hline & & & & & \multirow{3}{*}{$\begin{array}{l}\text { települé- } \\
\text { sek száma }\end{array}$} & \multicolumn{3}{|c|}{ lakónépessége } \\
\hline & \multirow[b]{2}{*}{ fo } & \multirow{2}{*}{$\begin{array}{c}\text { aránya az } \\
\text { országos- } \\
\text { ból, \% }\end{array}$} & \multirow[b]{2}{*}{ ezer $\mathrm{Ft}$} & \multirow{2}{*}{$\begin{array}{c}\text { az } \\
\text { országos } \\
\text { \%-ában }\end{array}$} & & \multirow[b]{2}{*}{ fo } & \multicolumn{2}{|c|}{ aránya, \% } \\
\hline & & & & & & & $\begin{array}{c}\text { a } \\
\text { lakosság- } \\
\text { ból }\end{array}$ & $\begin{array}{c}\text { az } \\
\text { országos- } \\
\text { ból }\end{array}$ \\
\hline $\begin{array}{l}\text { Györ-Moson- } \\
\text { Sopron }\end{array}$ & 425470 & 4,2 & 920 & 109 & 67 & 70256 & 16,5 & 1,9 \\
\hline Vas & 270386 & 2,7 & 960 & 114 & 77 & 34673 & 12,8 & 0,9 \\
\hline Zala & 299252 & 2,9 & 767 & 91 & 142 & 77846 & 26,0 & 2,1 \\
\hline $\begin{array}{l}\text { Nyugat- } \\
\text { Dunántúl }\end{array}$ & 995108 & 9,8 & 885 & 105 & 286 & 182775 & 18,4 & 4,9 \\
\hline Ország ósszesen & 10174342 & 100,0 & 842 & 100 & $207 l$ & 3726978 & 36,7 & 100,0 \\
\hline
\end{tabular}

Forrás: A területfejlesztési források felhasználása. KSH 1999.

A három megyének a decentralizált területfejlesztési célelỏirányzatokból (TFC, TERKI) való részesedése az országban a legalacsonyabb, és jelentős mértékben elmarad a többi régió megyéjébe érkezö források nagyságától (1996-2001 között mindőssze 6,8\%). Mivel a CÉDE megyék közötti felosztása nem kapcsolódik a kedvezményezett térségekben élö lakosság arányához, allokációja jóval kiegyenlítettebb a másik két célelöirányzatnál (a régió részesedése 1998-2001 
között 10,8\%). Mindazonáltal a CÉDE bevezetése sem változtatott számottevően a kialakult megyei arányokon, így az elmúlt hat esztendőben folyóáron számolva a Nyugat-dunántúli régió számára a három decentralizált forrás 7,6\%-a állt rendelkezésre. Az egyes célelőirányzatok megyei keretösszegét a 3. táblázat mutatja. Megfigyelhető, hogy a vizsgált időszakban összesen 4,77 Mrd Ft állt a három célelöirányzatból rendelkezésre. Ezen források összege évről-évre az inflációt meghaladó ütemben növekedett, ami azonban kizárólag a CÉDE-nek kőszönhetö, hiszen a TFC és a TERKI esetében a forrásnövekedés nem volt jelentős mértékủ.

\section{TÁBLÁZAT}

A megyei területfejlesztési tanácsok rendelkezésére álló támogatási keretösszeg a Nyugat-dunántúli régióban, 1996-1999, folyóáron, millió Ft

(Available Funds for Support of County Regional Development Committees in West Transdanubia)

\begin{tabular}{lrrrrrrr}
\hline Megyék & 1996 & 1997 & 1998 & 1999 & 2000 & 2001 & $1996-2001$ \\
\hline TFC & 107,2 & 119,4 & 170,3 & 179,6 & 168,6 & 132,1 & 877,2 \\
TERKI & 96,7 & 158,3 & 252,7 & 280,8 & 302,7 & 191,0 & 1282,2 \\
CÉDE & - & - & 152,2 & 221,7 & 240,9 & 230,7 & 845,3 \\
Györ-Moson-Sopron & 203,9 & 277,7 & 575,2 & 682,1 & 712,2 & 553,8 & 3004,7 \\
\hline TFC & 76,5 & 94,4 & 101,5 & 107,0 & 94,5 & 99,4 & 573,3 \\
TERKI & 75,7 & 129,1 & 150,2 & 166,9 & 164,3 & 165,0 & 851,0 \\
CÉDE & - & - & 127,0 & 189,0 & 203,2 & 195,1 & 714,3 \\
Vas & 152,2 & 223,5 & 378,7 & 462,9 & 462,0 & 459,5 & 2138,6 \\
\hline TFC & 115,3 & 149,1 & 150,8 & 159,0 & 151,9 & 129,3 & 855,4 \\
TERKI & 118,3 & 217,4 & 238,6 & 265,1 & 292,1 & 228,0 & 1359,5 \\
CÉDE & - & - & 160,0 & 240,1 & 262,2 & 250,5 & 912,8 \\
Zala & 233,6 & 366,5 & 549,4 & 664,2 & 706,2 & 607,8 & 3127,7 \\
\hline Nyugat-Dunántúl & 589,7 & 867,7 & 1503,3 & 1809,2 & 1880,4 & 1621,1 & 8271,0 \\
\hline
\end{tabular}

Forrás: Complex CD jogtár alapján saját számítás.

A megyék számára rendelkezésre álló decentralizált források nagyságától valamelyest eltért a szerződésekkel ténylegesen biztosított támogatások összege. Ez annak köszönhetö, hogy a megyei területfejlesztési tanácsnak a több évig tartó beruházások esetében lehetősége van a következő évre szóló támogatások 25-40\%-ának - lekötésére is. Így egy-egy évben a támogatás meghaladhatja a rendelkezésre álló keretösszeget. Tanulmányunkhoz az 1996-1999 közötti megyei területfejlesztési tanácsi határozatok álltak rendelkezésre, így vizsgálatunk erre a négy évre korlátozódik. A tényleges támogatások összege ezen időszak alatt majdnem elérte az 5 Mrd Ft-ot, ami mintegy 200 millió Ft-tal haladja meg a felhasználható keretösszeget (4. táblázat). 
A decentralizált területfejlesztési támogatások felhasználásának tapasztalatai a Nyugat-dunántúli régióban. Tér és Társadalom, 15. 2001. 2. 131-146. p.

\section{TÁBLÁZAT}

A megyei területfejlesztési tanácsok által megitélt tảmogatások szerzödés szerinti összege a Nyugat-dunántúli régióban, 1996-1999, folyóáron, millió Ft

(Supports of County Regional Development Committees Regional Development Supports in West Transdanubia)

\begin{tabular}{lrrrrr}
\hline Megyék & 1996 & 1997 & 1998 & 1999 & $1996-1999$ \\
\hline TFC & 109,5 & 138,1 & 209,7 & 123,7 & 581,0 \\
TERKI & 104,7 & 177,5 & 281,7 & 292,1 & 856,0 \\
CÉDE & - & - & 166,7 & 233,0 & 399,7 \\
Györ-Moson-Sopron & 214,2 & 315,6 & 658,1 & 648,8 & 1836,7 \\
\hline TFC & 99,1 & 89,0 & 109,1 & 110,0 & 407,2 \\
TERKI & 49,3 & 143,7 & 154,5 & 84,7 & 432,2 \\
CÉDE & - & - & 134,2 & 145,1 & 279,4 \\
Vas & 148,5 & 232,7 & 397,8 & 339,7 & 1118,7 \\
\hline TFC & 159,1 & 137,4 & 163,9 & 156,0 & 616,4 \\
TERKI & 164,6 & 256,2 & 245,6 & 295,7 & 962,1 \\
CÉDE & - & - & 187,2 & 230,4 & 417,6 \\
Zala & 323,7 & 393,6 & 596,7 & 682,1 & 1996,1 \\
\hline Nyugat-Dunántúl & 686,4 & 941,9 & 1652,6 & 1600,0 & 4951,5 \\
\hline
\end{tabular}

Forrás: Megyei területfejlesztési tanácsok adatai alapján saját számítás.

\section{A megyei területfejlesztési források felhasználása a Nyugat-dunántúli régióban}

A régióban a közel $5 \mathrm{Mrd} \mathrm{Ft}$ támogatás összesen több mint $34 \mathrm{Mrd} \mathrm{Ft}$ értékủ beruházás megvalósulásához járult hozzá az elmúlt négy évben. Ez a gazdasági szervezetek által megvalósított beruházások összegének (678 Mrd Ft) mindössze $5 \%$-át jelentette. Győr-Moson-Sopron megyében a gazdasági szervezetek által megvalósított, összesen 390 Mrd Ft értékủ beruházáshoz képest mindössze 14,2 Mrd Ft volumenü beruházáshoz járult hozzá a tanács, míg Vas megyében még ennél is kisebb volt a támogatásban részesült beruházások aránya az összeshez viszonyítva $(2,9 \%)$. Ezzel ellentétben viszonylag magas Zala megyében, ahol elérte a 12\%-ot (5. táblázat). A nagy eltérés oka valószínüleg abban keresendő, hogy Zala megyében eleve elmaradt a beruházások volumene a másik két megyétöl. A megvalósult fejlesztések összköltségükhöz viszonyítva átlagosan Györ-MosonSopron és Zala megyében 13-14\%, Vas megyében 23\% támogatásban részesültek. $\mathrm{Az}$ arányokat jelentös mértékben torzítja azonban, hogy több, egy milliárd forintot meghaladó beruházás is részesült néhány millió Ft-os támogatásban (pl. Lövő szennyvízcsatorna, Fine-Frost Hütö- és Élelmiszeripari Kft. beruházása stb.). A támogatások aránya a TFC-böl támogatott pályázatok esetében volt a legkisebb (8-11\%), ami elsősorban annak köszönhetö, hogy a TFC támogatások egy része a 
magasabb saját részt vállalni képes vállalkozói körben került felhasználásra, míg a TERKI és a CÉDE a gazdasági szféránál forráshiányosabb - különösen a kedvezményezett térségekben és településeken - ơnkormányzatok által megvalósitott fejlesztések megvalósulását segítette. Az arány Győr-Moson-Sopron megyében a CÉDE támogatásoknál megközelítette a $60 \%$-ot, Vas megyében pedig a TERKI támogatásoknál elérte az 50\%-ot.

\section{TÁBLÁZAT}

A támogatásban részesült beruházások aránya a gazdasági szervezetek összes beruházásához képest a Nyugat-dunántúli régióban, \%

(The Share of Supported Investments in All Investments of Economic Sector in West Transdanubia)

\begin{tabular}{lrrrrr}
\hline Megyék & 1996 & 1997 & 1998 & 1999 & $1996-1999$ \\
\hline Györ-Moson-Sopron & 3,7 & 3,7 & 6,0 & 2,2 & 3,7 \\
Vas & 2,1 & 1,8 & 4,7 & 2,5 & 2,9 \\
Zala & 11,6 & 10,9 & 7,9 & 19,8 & 12,0 \\
\hline Nyrugat-Dunántúl & 4,5 & 4,5 & 6,1 & 4,5 & 5,0 \\
\hline
\end{tabular}

Forrás: Megyei területfejlesztési tanácsok és KSH alapján saját számitás.

A TFC forrásokból - eltérỏen a másik két célelöirányzattól - az önkormányzatok mellett gazdasági szervezetek által benyújtott pályázatokhoz is támogatás biztosítható. Az egyes megyékben e tekintetben jelentős eltérések voltak tapasztalhatók. Míg Vas megyében az önkormányzatokra koncentrált (több mint 85\%-a), Györ-Moson-Sopron megyében közel kiegyenlített volt a két kör támogatása, Zala megyében pedig kétharmada a vállalkozások által megvalósított fejlesztések támogatására irányult. A vállalkozások által elnyert támogatások felhasználását tekintve kiderull, hogy Györ-Moson-Sopron és Zala megyében elsösorban munkahelyteremtésre (75, illetve $83 \%$ ) forditódott, míg Vas megyében a termel6 infrastruktúra fejlesztése kiemeltebb szerepet kapott (közel 60\%), és csak második helyen szerepelt a munkahelyteremtés (32\%). Az önkormányzatok által megvalósított fejlesztések, beruházások esetében már sokkal elókelőbb helyen szerepeltek az infrastrukturális beruházások. A támogatásokból való részesedésủk a három megyében elérte a $85-95 \%$-ot is, azonban, ha a támogatásban részesült pályázatok számát tekintjük, mindenképpen meg kell említeni a különböző fejlesztési koncepciók készítését is (kistérség fejlesztési koncepciók, vidékfejlesztési programok, integrált gazdaságfejlesztési tervek stb.). Ezek támogatási igénye - köszőnhetően az alacsony összköltségnek - nem volt jelentős, azonban megyénként 10-20 dokumentum elkészítését tette lehetơvé a vizsgált négy év során, és a hozzájárulás általában a jogszabályi lehetőségek biztosította 70\% kőrul alakult. A TFC támogatások kistérségi eloszlásában is jelentỏs eltérések figyelhetôk meg. Népességarányosan különösen magas támogatásban részesültek az egyébként kedvezményezett térségek: a kapuvári, a Tét-pannonhalmi, a csepregi, a lenti, valamint a zalaszentgróti kistérség. 
A TERKI támogatások a kedvezményezett térségek és települések önkormányzatainak beruházásaira használhatók fel, döntően a térségi hátrányok felszámolása érdekében, a már fentebb leírtakkal kiegészítve. Mivel Győr-MosonSopron megyében 1996-ban mindössze egy ilyen kistérség volt (19 településsel), nem volt elegendő pályázó a keretösszegre. A probléma feloldása érdekében a tanács döntése során rugalmasan azokat a pályázatokat is elfogadta, amelyek az 1996-ban elkészült megyei területfejlesztési koncepció szerint elmaradottnak minősített térségekből érkeztek ${ }^{10}$. A másik két megyében nem volt hasonló jellegü probléma. A régió egészében általában az új létesítmények élveztek elsőbbséget, és kiemelkedő volt a termelö infrastruktúra-beruházások aránya. Míg Győr-MosonSopron és Vas megyében több mint $95 \%$ e cél mentén került felhasználásra, Zalában is elérte a 75\%-ot. A termelőinfrastruktúra fejlesztéseken belül különös hangsúllyal szerepelt a szennyvízhálózat és a gázhálózat kiépítése, valamint az útépítés és -korszerüsités. Ezen projektek jelentőségét tovább növeli, hogy megvalósításuk sok esetben szoros települések közötti együttműködést igényelt (közös szennyvíztisztító, közös gázprogram stb.), így nagymértékben hozzájárult a települések közötti együttmúködések kialakulásához és a kistérségi kapcsolatok elmélyüléséhez. A termelöinfrastruktúra elsődlegességét indokolta a jelentős elmaradottság az országos átlagtól - különösen Vas és Zala megye aprófalvas térségeiben -, aminek részben oka, hogy az 1990-es évtized elsỏ felében a Területfejlesztési Alap (TEFA) a termelőinfrastruktúra kiépitésében erỏteljesen az ország keleti részére koncentrált (föként Borsod-Abaúj-Zemplén, SzabolcsSzatmár-Bereg és Hajdú-Bihar megyékre). Az infrastrukturális beruházások mellett - annak támogatásánál jóval kisebb összegben - más célokra is jutott a TERKI-ből. Így például - Zala megyében a termál program keretében - támogatásban részesültek turisztikai célú fejlesztések, felszíni vízelvezetéshez kapcsolódó beruházások, szociális célú közhasznú munkák, illetve néhány önkormányzati intézményfejlesztés is. A Zala megyei támogatások felhasználása annak viszonylagos szétaprózottságával is eltér a másik két megyétől. Míg Györ-MosonSopron és Vas megyében a négy év alatt 69, illetve 74 támogatásban részesített pályázat volt, addig Zala megyében ugyanezen idö alatt ennek háromszorosa (214). Ez részben az aprófalvas településszerkezettel magyarázható, míg Vas megyében a rendelkezésre álló források korlátozottsága (az országban a legalacsonyabbként, mindössze kétharmada volt a Zala megyeinek) azok nagyobb koncentrációját igényelte. Ha a támogatások kistérségek közötti eloszlását vizsgáljuk, megállapítható, hogy az egy före jutó támogatás - a TFC-hez hasonlóan - a csornai, a Tét-pannnonhalmi, a vasvári, a lenti, a letenyei és a zalaszentgróti kistérségekben volt a legmagasabb.

Az előző két célelőirányzattól eltérően a CÉDE nem kifejezetten területfejlesztési célú, területi kiegyenlítést szolgáló eszköz. Ez, valamint a célelőirányzat felhasználásának központi szabályozása más jellegủ felhasználásra predesztinálja a megyei területfejlesztési tanácsokat. İgy lehetőség nyílik bizonyos mértékben humán infrastrukturális jellegủ fejlesztések megvalósítására is (oktatási, 
egészségügyi, kulturális intézmények fejlesztése). A három megyében a vizsgált négy év során egyaránt körülbelül 110-110 pályázat részesült támogatásban, azonban míg Györ-Moson-Sopron és Zala megyében az átlagos támogatás mértéke 4 millió $\mathrm{Ft}$ körül alakult, addig Vas megyében nem érte el a 2,5 millió $\mathrm{Ft}$-ot. Ez részben ugyancsak a Vas megyei források alacsony összegével magyarázható. Míg Györ-Moson-Sopron és Vas megyében az önkormányzati intézmények korszerüsítése, fejlesztése kapott nagyobb hangsúlyt (70, illetve 64\%), addig Zala megyében a CÉDE támogatások 60\%-át infrastrukturális beruházások megvalósitására használták fel. Általánosan megállapítható azonban, hogy elsősorban az alacsonyabb beruházási költségeknek köszönhetb̋en - az intézményfejlesztéssel kapcsolatos támogatások aránya azok összköltségéhez viszonyítva 2-3-szor magasabb volt, mint az infrastruktúra-fejlesztés területén. Györ-Moson-Sopron megyében az elmaradottabbnak számító Tét-pannonhalmi kistérségben, Vas és Zala megyében ezzel szemben a kevésbé hátrányos helyzetü sárvári és Keszthely-hévízi kistérségben volt a legmagasabb az egy före jutó CÉDE támogatások összege.

\section{A támogatások illeszkedése a megyei koncepciók programjaihoz}

A területfejlesztési célelöirányzatból rendelkezésre álló források felhasználásának értékelése során szükség van a felhasználás, illetve a megyei területfejlesztési koncepciókban megfogalmazott programok közötti kapcsolat vizsgálatára. Erre lehetöségünk van, hiszen a régió megyéi élen jártak a területfejlesztési stratégiák készítésében. 1996-ra, amikor bevezetésre kerültek a decentralizált források, tulajdonképpen mindhárom megyében elkészült a koncepciók elsỏ változata, amelyekben már megfogalmazásra kerültek a később elfogadott prioritások. A megyei területfejlesztési tanácsok a támogatásokra beérkezett pályázatok elbirálásakor természetesen a koncepcióban meghatározott programok szerint próbálnak meg prioritást alkotni, azonban ez nem minden esetben lehetséges. Elsősorban a CÉDE források felhasználásánál, de a TFC és a TERKI támogatások esetében is jelentős mértékben korlátozó tényezőként kell számba venni a célelőirányzatok felhasználására vonatkozó központi szabályozást.

Győr-Moson-Sopron megyében a vizsgált időszakban összesen 266 pályázat részesült támogatásban. A 85 TFC támogatás több mint fele $(52,4 \%)$ a koncepcióban megfogalmazott településhálózat és vidékfejlesztés, egyharmada (34,3\%) pedig a gazdasági szerkezet és a környezet fejlesztése prioritások megvalósulásához járult hozzá közvetlenül. Mindössze hét pályázat (a támogatások 13,3\%-a) nem kapcsolódott közvetlenül a programokhoz, azonban a tanács szándéka szerint természetesen közvetve azok is annak megvalósítását szolgálták. A TERKI támogatások - célrendszerének köszönhetően - teljes mértékben megfeleltek a koncepció prioritásainak. A 69 támogatott pályázat (több mint $900 \mathrm{M} \mathrm{Ft}$ ) az 5. prioritással hozható közvetlen kapcsolatba (Településhálózat és 
vidékfejlesztés, azon belül is elsősorban a térségi infrastruktúra fejlesztése program). A CÉDE források felhasználásánál - a központi szabályozásnak köszönhetỏen - már jóval mérsékeltebb a kapcsolat, a 112 pályázatból mindössze 30 (a támogatások 29,4\%-a) segíti a koncepció megvalósulását (ugyancsak az 5. prioritással összefüggésben). Megállapítható, hogy összességében a decentralizált területfejlesztési támogatások döntő többsége ( $80 \%$-a a a összes pályázatnak pedig kétharmada) közvetlenül kapcsolódik a megyei területfejlesztési koncepcióban meghatározott prioritásokhoz. Mindazonáltal mindenképpen meg kell említeni a források felhasználásának koncentráltságát. A tanács által megítélt támogatások a koncepcióban megfogalmazott hat prioritás közül mindőssze kettőt támogattak, és e kettő közull is közel $90 \%$-uk a már többször említett településhálózat és vidékfejlesztés célt szolgálta. Olyan megfogalmazott prioritások ezzel szemben nem részesültek támogatásban a megyei decentralizált forrásokból, mint a humánerőforrás-fejlesztés, a multi- és interregionális kapcsolatok szélesitése, a megyeszervezés, vagy a környezet állapotának javítása.

Vas megyében ơsszesen 283 pályázat nyert támogatást a három decentralizált elöirányzat valamelyikéből 1996-1999 között a megyei teruletfejlesztési tanács döntése alapján. A támogatásban részesített pályázatok majdnem 90\%-a közvetlenül szolgálta a Vas megyei területfejlesztési koncepcióban meghatározott prioritások megvalósítását. Ugyanakkor a felhasználás célját tekintve - a GyörMoson-Sopron megyeihez hasonlóan - ugyancsak érvényesült a koncentráció, hiszen az összes támogatás $80 \%$-a a vidékfejlesztés, térségi felzárkóztatás prioritás megvalósulásához járul hozzá elsődlegesen (ezen belül is előtérbe helyezve az infrastruktúra-fejlesztési programokat). E prioritás mellett Vasban is mindőssze a gazdaságfejlesztés (a gazdaság összehangolt fejlesztése) részesült támogatásban, melynek részesedése azonban a TFC esetében is csak $17,5 \%$ volt. A gazdaságfejlesztéshez kapcsolódó támogatások konkrét célja általában a munkahelyteremtés, és/vagy megörzés volt. Ellentétben Györ-Moson-Sopron megyével, Vasban a CÉDE támogatások nagyobb része (kétharmada) is kapcsolatba hozható a koncepcióban foglalt célokkal. Összességében megállapítható, hogy a rendelkezésre álló források felhasználása néhány kiemelt program támogatására koncentrált annak ellenére, hogy a Vas megyei területfejlesztési koncepcióban meghatározásra kerult öt prioritáshoz 29 konkrét program kapcsolódik. Hasonlóan Györ-Moson-Sopron megyéhez, nem szerepelt célként a megyei decentralizált pénzeszközök felhasználása során sem a humáneröforrás-fejlesztés, sem a multi- és interregionális kapcsolatok fejlesztése, sem a természet- és környezetvédelem célkitüzése.

A decentralizált megyei területfejlesztési célelőirányzatok felhasználását illetően Zala megyében is a támogatások $85 \%$-a (a TFC támogatások $100 \%$-a, a TERKI támogatások közel 90\%-a, a CÉDE támogatások 59\%-a) közvetlenül kapcsolódik a megyei koncepcióban megfogalmazott fejlesztési prioritásokhoz. Ez az összes 457 támogatásban részesített pályảzatból 386-ot jelent. A TFC források felhasználása 
során a célelóirányzat majd kétharmada a gazdaságfejlesztési prioritás megvalósulásához járult hozzá, míg egyharmada müszaki infrastrukturális beruházásokat szolgált. A TERKI természetesen elsósorban a müszaki infrastruktúra-fejlesztésre koncentrált, és a CÉDE támogatások is egyértelmüen e prioritảst részesítették elönyben. A gazdaságfejlesztés és a müszaki infrastruktúrafejlesztés mellett még két további prioritás részesült - az elózóeknél jóval kevesebb - támogatásban: a vidékfejlesztés és a környezeti értékek megóvása.

A rendelkezésre álló decentralizált források felhasználását vizsgálva egyértelmüen megállapítható, hogy az a Nyugat-dunántúli régióban összhangban van a megyei területfejlesztési koncepciókban meghatározott célkitủzésekkel, prioritásokkal. A megyei teruletfejlesztési tanácsok forráselosztási gyakorlatában elsőbbséget élveznek a koncepció prioritásainak megvalósulását szolgáló projektek. Egyeduuli kivételt jelent a CÉDE támogatások elosztása, melynek központi szabályozása jóval korlátozottabb lehetơségeket ad a tanácsok számára. E források esetében különősen nagy súlyt képviseltek az ơnkormányzat által kezelt ingatlanok (iskolák, óvodák, müvelöđési házak, polgármesteri hivatalok) rekonstrukciójảra, felújítására, bơvítésére felhasznált támogatások. Megemlítendő azonban, hogy a koncepciók prioritásrendszere a fejlesztések rendkívull széles körét ölelik fel, a gazdasági-, társadalmi-, környezeti fejlesztések szinte minden területére kiterjednek. Ennek ellenére megfigyelhetó, hogy a források a vizsgált idöszakban, mindhárom megyében mindössze néhány prioritásra - elsősorban a müszaki, illetve termelö infrastruktúra-fejlesztésre, valamint a gazdaságfejlesztésre - koncentráltak. Nem, vagy csupán mérsékelten részesültek ugyanakkor támogatásban olyan fejlesztési célok, mint a humánerőforrás-fejlesztés, a multi- és interregionális kapcsolatok, vagy a természet- és környezetvédelem.

\section{Megfogalmazható tapasztalatok}

Megállapítható, hogy a területfejlesztési törvénnyel és a törvény által elöirt források bizonyos részének a megyékhez való rendelésével egyértelmủen elindult a területfejlesztési források decentralizációja. Bár a decentralizált eszkőzoỏk megyék közötti elosztása a területi egységek fejlettségbeli különbségét viszonylag jól tuukrözi, a rendelkezésre álló keretösszegek első néhány évben tapasztalható reálértéken történö lassú növekedése megtorpanni látszik. A decentralizált területfejlesztési források GDP-hez mért összege rendkívull csekélynek mondható. Országos szinten épp hogy csak eléri a 0,2\%-ot, ami a fejlettebb térségekben - ahol a GDP relatíve magasabb, míg a terulletfejlesztési tanácsok számára rendelkezésre álló eszközök jóval szükősebbek (lásd Vas megye) - még jóval alacsonyabb.

Ennélfogva a megyei decentralizált területfejlesztési források nagyságuknál fogva nem voltak képesek számottevóen befolyásolni a megvalósuló beruházások alakulását, és ezzel a térség hosszú távú fejlődését. Mint azt a megyei területfejlesztési tanácsok munkaszervezeteinek vezetỏi kőzül tőbben is 
megjegyezték, a források jelenlegi mértéke nem alkalmas a hosszú távú stratégiai gondolkodás érvényesítésére. Szerény mértékük ellenére is számottevően hozzájárultak azonban a megyék gazdaságának növekedési pályára állásához szükséges feltételek megteremtéséhez, de legnagyobb érdemüknek talán az tekinthetö, hogy hozzájárultak az Európai Unióban is elfogadott területi politika kialakításához, az új típusú területfejlesztés intézményrendszerének kiépüléséhez, valamint szerepưk megerősödéséhez. Ezt bizonyítja, hogy a Nyugat-dunántúli régióban megyénként 10-20 kistérségi fejlesztési stratégia, program, tervdokumentum elkészítéséhez biztosított - általában a jogszabály által engedélyezett legmagasabb (70\%) - támogatást.

Bár a decentralizált források felhasználásáról a megyei területfejlesztési tanácsok dönthetnek, azonban az erős központi meghatározottság miatt a követendő célok sokkal inkább az általános terúletpolitikai célkitüzéseket követik, semmint az egyes területi egységekben megfogalmazásra került fejlesztési elképzeléseket. Az alapvetően eltérỏ célokat szolgáló fejlesztési források különbözősége (területi kiegyenlítés, infrastruktúra-fejlesztés, munkahelyteremtés, gazdaságfejlesztés, önkormányzati intézményfejlesztés) sokszor nehézséget okozhat az átláthatóság tekintetében, illetve több esetben a területi szereplök és források megosztottságához vezethet. Ugyanakkor, figyelembe véve, hogy a támogatások általában tényleges értékuik többszörösét voltak képesek megmozgatni a különbözö fejlesztések érdekében kiderül, hogy bizonyos mértékben alkalmasak a térségi erőforrások hatékony koordinálására.

A hatékonyság növelése, valamint az alulról jövő elképzelések és a helyi speciális - megyénként, térségenként más és más - igények és megfogalmazásra kerult célok megvalósitása érdekében szükség lenne a jelenlegi rendszer újragondolására. Ezek a reformok azonban természetesen nem választhatók el az Európai Unióhoz való csatlakozással egyre inkább felértékelődő regionalizációs tơrekvések megvalósításától, a különbözö területi szintek funkcióinak, feladatainak, azok lehetséges intézmény- és eszkőzrendszerének pontos definiálásától. Erre nemcsak az EU regionális politikájának való megfelelés és a strukturális alapok fogadása, hanem legalább olyan mértékben a haza területi politika hatékonyságának optimalizálása miatt is szükség van.

\section{Jegyzetek}

1 MTA RKK Nyugat-magyarországi Tudományos Intézet, Győr.

${ }^{2}$ 1996. évi XXI. tv. a területfejlesztésról és a területrendezésröl.

${ }^{3}$ A területfejlesztési célelöirányzat neve a teruletfejlesztésnek a Környezetvédelmi és Teruletfejlesztési Minisztériumtól a Fôldművelési és Vidékfejlesztési Minisztériumhoz tơrténó áthelyezését és a politika irányvonalában bekơvetkezett hangsúlyeltolódást kơvetve 1999-ben vidékfejlesztési célelöirányzatra (VFC) változott, majd 2000-töl ismét területfejlesztési célelöirányzat lett. Jelen tanulmányban az egyszerüség kedveért mindvégig terưletfejlesztési célelőirányzatként (TFC) hivatkozunk rá. 
4 89/2001. (VI. 15.) Korm. rendelet a területfejlesztési célelőirányzat felhasználásának részletes szabályairól (illetve a már hatályon kívưi helyezett, előző évekre vonatkozó jogszabályok).

${ }^{5} 91 / 2001$. (V1. 15.) Korm. rendelet a teruletfejlesztés kedvezményezett térségeinek jegyzékéröl (illetve a már hatályon kívül helyezett, elözö évekre vonatkozó jogszabályok).

6 32/1998. (11. 25.) Korm. rendelet a területi kiegyenítést szolgáló fejlesztési célú támogatások felhasználásának részletes szabályairól.

7 9/1998. (1. 23.) Kormányrendelet a helyi ônkormányzatok címzett és céltámogatásának, a céljellegủ decentralizált támogatásának igény-bejelentési, döntés-elökészítési és elszámolási rendjéröl, valamint a Magyar Államkincstár finanszírozási, elszámolási és ellenőrzési feladatairól, továbbá a TÁKISZ feladatairól. 7001/1998. (BK 9.) BM irányelv a céljellegủ decentralizált támogatás pályázati rendszerének mükődtetéséröl.

${ }^{8}$ 24/2001. (IV. 20.) OGY határozat a teruletfejlesztési támogatások és a decentralizáció elveiröl, a kedvezményezett térségek besorolásának feltételrendszeréröl (illetve az általa hatályon kívull helyezett 30/1997. OGY határozat a terủletfejlesztési támogatások és a decentralizáció elveiről, a kedvezményezett térségek besorolásának feltételrendszeréról).

${ }^{9}$ Györ-Moson-Sopron megyében 1996-ban egy kedvezményezett kistérség volt (19 település), 1997-ben mindőssze 10 kedvezményezett település, 1998-tól pedig két kedvezményezett kistérség (ősszesen 61 telepullés) és hat kedvezményezett telepulés. Vas megyében 1996-ban egy kedvezményezett kistérség volt (23 település), de a kör 1998-tól további eggyel bövült (22 település), és 1997-tól 33 telepulés isø kedvezményezettnek számít. Zala megyében 1996-tól kezdve három kedvezményezett kistérség taláiható (összesen 103 település). 1997-ben ezen kívül 45, 1998-tól pedig 43 település tartozik még a kedvezményezettek körébe.

10 Többek között a Györ-Moson-Sopron megyei teruletfejlesztési koncepció során készúlt vizsgálatoknak is köszơnhető, hogy 1998-tól a csornai és a Tét-pannonhalmi kistérség bekerült a kedvezményezett térségek kőzé.

\section{Irodalom}

A regionális szintũ területfejlesztés finanszirozási rendszerének megalapozása. (2000) Győr, MTA RKK Nyugat-magyarországi Tudományos Intézet. Kutatási zárójelentés.

A területfejlesztési források felhasználása. (1999) Budapest, KSH.

A területfejlesztési koncepciók és programok összehasonlitó értékelése. (2000) Györ, MTA RKK Nyugat-magyarországi Tudományos Intézet. Kutatási zárójelentés.

Javaslatok a megyék és a tervezési-statisztikai régiók támogatási eszközrendszerére és a programok végrehajtásának intézményrendszerére. (1998) Pécs, MTA RKK Dunántúli Tudományos Intézet. Kutatási zárójelentés.

Györ-Moson-Sopron megye területfejlesztési stratégiája. (1996) Györ, MTA RKK Nyugatmagyarországi Tudományos Intézet.

Vas megye területfejles:tési koncepciója. (1998) Szombathely, MTA RKK Nyugat-magyarországi Tudományos Intézet Vas megyei Kutatócsoport.

Zala megye területfejlesztési koncepciója - l. kötet. (1997) Zalaegerszeg, Pylon Kft. 


\title{
EXPERIENCES OF THE EXPENDITURES OF THE DECENTRALISED REGIONAL DEVELOPMENT SUPPORTS IN WEST TRANSDANUBIA
}

\begin{abstract}
ANDRÁS GROSZ
The decentralisation of regional supports started in 1996 with the pass of the act on regional development and physical planning and the decentralisation to counties of a certain share of regional development sources. The differences in the level of socio-economic development of the counties is reflected in the distribution of the funds, but the current amount of these sources is extremely small (about $0,2 \%$ in the country) so they are unsuitable for the implementation of strategic priorities in the long term. However these supports assisted to the initiation of the required conditions for a dynamic development of the counties. Nevertheless they considerably contributed to the formation of an EU-compatible institutional and financing system of regional development in Hungary. The paper's aim is to present the most important experiences of the expenditure of the regional development funds in county level. Beside some general information on the principle and the regulation of the decentralisation and the distribution of the funds between the counties, we would like to examine the projects supported by the county development councils in West Transdanubia between 1996 and 1999.
\end{abstract}

